\title{
A case study on novel natural remedy (Trichosanthes dioica Roxb.) against bacillary white diarrhea in broiler chickens
}

\begin{abstract}
The bacillary white diarrhea disease is one of the most threaten disease in poultry birds especially broilers, caused by Salmonella pullorum. The major sign of this disease are white diarrhea, in appetence, depression, ruffled feathers, closed eyes, loud chirping, vent pasting, gasping, and lameness. The Trichosanthes dioica (family: Cucurbitaceae), commonly known as "Sespadula \& Pointed gourd" in English, "Parwal" in Hindi and "Kovakka" in Tamil, is widely grown throughout India. The leaves of this plant have also been used in traditional system of medicine for overcoming problems like constipation, fever, skin infection, wound healing and also in gastric ulcer. In the present study, fine paste of leaves of T. dioica was evaluated for its anti bacillary white diarrhea disease on broilers by four days medication. Amoxycillin ( $10 \mathrm{mg} / \mathrm{kg}$ of body weight of broiler) was used as the standard drug (T0). Different concentrations ( 0.5 to $2 \mathrm{gm} / \mathrm{kg}$ : each concentration of treatment was given once and twice per day- as T1-T6 respectively) of T. dioica were administrated with sterile water. The treatment results revealed that the T4, T5 and T6 treatment doses were shown better curing activity (100\%) against bacillary white diarrhea. Further, it simultaneously increases the feed intake rate (as T4: 129.9gm, T5: 152.6gm T6: 153.3gm) and gradually increase weight of broiler chicken (as T4: $129.9 \mathrm{gm}$, T5: $152.6 \mathrm{gm}$ T6: $153.3 \mathrm{gm}$ ) than T2 \& $\mathrm{T} 3$ and results are almost similar with the result of T1 (standard). In conclusion, the present study provides preliminary records on anti bacillary white diarrhea potential of fresh leaves pastes of T. dioica.
\end{abstract}

Keywords: natural medicine, T dioica, antibacillary, S. pullorum, diarrhea
Volume 3 Issue 2 - 2018

N Mathiyazhagan, K Suresh, C Deepa

PG and Research Centre in Biotechnology, MGR College, India

Correspondence: N Mathiyazhagan, PG and Research Centre in Biotechnology, MGR College, India,

Email mathimicro@gmail.com

Received: March 28, 2017 | Published: April 24, 2018

\section{Introduction}

The bacillary white diarrhoea disease caused by one of the two poultry-adapted strains of Salmonella bacteria, Salmonella pullorum, this usually causes mortality in birds only up to 3 weeks of age of broilers. Occasionally it can cause losses in adult birds and brown-shell egg layers. ${ }^{1}$ It affects broiler chickens most commonly, but also infects turkeys, game birds, guinea fowls, sparrows, parrots, ring doves, ostriches and peafowl. It still occurs worldwide in commercial systems and non-commercial poultry system. Morbidity is $10-80 \%$; mortality is increased in stressed or immune compromised flocks and may be up to $100 \%{ }^{2}$ The route of infection is oral or via the navel/yolk. Transmission may be transovarian or horizontal mainly in young birds and may sometimes be associated with cannibalism. The bacterium is fairly resistant to normal climate, surviving months but is susceptible to normal disinfectants. ${ }^{1}$ The major symptoms of this disease are white diarrhea, in appetence, depression, ruffled feathers, closed eyes, loud chirping, vent pasting, gasping, and lameness. ${ }^{3}$ Medicinal plants are the foundation of many important drugs of the modern world. In nature many plants and plants seed provided source of medicine at the earlier times. Plants have proven to be the most useful in curing diseases and provide an important source of pharma and medicine for human and livestock animals and birds. ${ }^{4}$ Trichosanthes dioica Roxb. (family: Cucurbitaceae), commonly known as "Sespadula \& Pointed gourd" in English, "Parwal" in Hindi and "Kovakka" in Tamil, is widely grown throughout India. ${ }^{5}$ Fruits of this plant are used as vegetable in Indian traditional food system from time immemorial. Besides fruits, other parts of the plant, such as the leaves and tender shoots, have also been used in the traditional system of medicine since ancient times. ${ }^{6}$ some specific medicinal properties have been identified, viz., hypocholesterolemic, hypoglyceridimic, and hypophospholipemic when shade-dried fruits were mixed in the food of non diabetic animals. ${ }^{6,7}$ Recently, its seeds and leaves have also been found as anti diabetic agents by Prashant Kumar Rai ${ }^{8,9}$ It also serves as a rich source of vitamin C. ${ }^{6}$ Hence several pharmacological studies have been carried out in different parts of $T$. dioica. Despite, the various claims on $T$. dioica medicinal uses, particularly its potential to heal bacillary white diarrhea diseased broiler chicken, no attempt has been made to our best knowledge. Based on these considerations, a case study was conducted to evaluate the efficiency of $T$. dioica as herbal medicine on bacillary white diarrhoea diseased broiler chicken caused by Salmonella pullorum.

\section{Material and methods}

\section{Selection of diseased I 5 days old broiler chicken}

The bacillary white diarrhea diseased broiler chicken was collected from broiler farm of Venkateshwara poultry ltd and 
reared in the separate shed. The disease was confirmed by veterinarian doctor of Thiyagadurgam Government veterinary hospital, Kallakurichi, Villupuram district of Tamilnadu, based on their sign of disease white diarrhea, inappetance, depression, ruffled feathers, closed eyes, loud chirping, vent pasting, gasping, and lameness.

\section{Preparation of Trichosanthes dioica for treatment}

The leaf of Trichosanthes dioica plant were freshly collected from the field and washed it with clean water and grinded it to get paste. This paste was dissolved in different concentration with clean water for treatment. ${ }^{10}$

\section{Trichosanthes dioica treatment}

There was no alteration on broiler diet, i.e as usual standard company feed is fed for all diseased broilers. The commercial drug Amoxycillin was used as a control. Different dose of fine grinded paste was dissolved in pure water as follows for treatment.

\section{The treatments are:}

T0: Amoxycillin (10mg/kg of body weight of broiler) as standard

T1: $0.5 \mathrm{gm}$ leaf paste of $T$. dioica in $15 \mathrm{ml}$ of sterile water at once a day

T2: $0.5 \mathrm{gm}$ leaf paste of $T$. dioica in $15 \mathrm{ml}$ of sterile water at twice a day

T3: $1 \mathrm{gm}$ leaf paste of $T$. dioica in $15 \mathrm{ml}$ of sterile water at once a day

T4: $1 \mathrm{gm}$ leaf paste of $T$. dioica in $15 \mathrm{ml}$ of sterile water at twice a day

T5: $2 \mathrm{gm}$ leaf paste of $T$. dioica in $15 \mathrm{ml}$ of sterile water at once a day

T6: $2 \mathrm{gm}$ leaf paste of $T$. dioica in $15 \mathrm{ml}$ of sterile water at once a day

For each treatment three bacillary white diarrhoea diseased broiler chickens were taken and the treatments were triplicated and the total treatment period was 4 days.

\section{Parameters of performance}

All the chickens under the study were weighed pre and post treatment and calculated amount of feed consumed. Further disease recovery percentage (\%) on day basis (4 days) was measured, based on recovering gradually from white diarrhea, depression, freshness of feathers, healthy eyes, slowly reduced loud chirping, vent pasting, gasping and lameness.

\section{Results and discussion}

The results of this study were clearly tabulated on Table 1 . It clearly states that the fresh leaf paste of $T$. dioica with different concentration/dose on bacillary white diarrhea diseased broiler chicken shows different level of results on disease recovery swiftness, feed intake range and chicken lived and changes in weight after treatment. The treatment with T4 \& T5 shows effective result on disease curing $(100 \%)$ and gradually increase the feed intake by diseased broiler (129.9 and 152.6 gm respectively) and it was comparable with the treatment of control (144.7 gm). Further the weight of the chickens was also increased progressively as 370.4 and $378.6 \mathrm{gm}$ on T4 and T5 treatment respectively. However the increase dose of T6 treatment twice per day was also showing similar range of result on bacillary white diarrhea infected broiler by $S$. pullorum. Gang Zhou used and reporter as maggot antimicrobial peptides are effective against $S$. pullorum diseased chicken. ${ }^{1}$ The results of the present treatment states that the $2 \mathrm{gm}$ (T4 \& T5) of fresh leaf paste is optimized range (administrated twice and once per day respectively) for curing the disease and gradually increase the feed intake and not essential of providing increase quantity of fresh paste of $T$. dioica. These results also states that, plant simultaneously increases the feed intake and digestibility nature of broiler under medication, hence it's steadily improve the feed intake by broiler chickens with disease curing. Salaheen et al. ${ }^{11}$ were carried out similar type of work with different plant sources and revealed that the byproducts of berry juice can be used as alternative and natural inhibitors for Salmonella gallinarum and Salmonella pullorum on chickens. ${ }^{11}$. The $\mathrm{T} 1$ treatment results were ineffective, since the chickens were died in the middle of treatment. Further, the T2 and T3 concentration treatments were less effective on disease curing (65\&80\%), feed intake (53.4 \&71.3gm) and weight enhancement (320.2 \& 358.4 gm). The bacillary white diarrhea disease curing activity of this $T$. dioica plant leaf paste fully depends on the phytochemical property of the plant. This statement was acceptable with the finding of various researchers on $T$. dioica. ${ }^{12,13}$ They declared that the presence of various phytoconstituents like tannins, saponins ${ }^{12,14}$, flavonoids, alkaloids, vitamin A \& C and triterpenoids ${ }^{15}$ of $T$. dioica responsible for therapeutic nature to various disease. Thus it can be suggested that presence of saponins and flavonoids may be responsible for T. dioica antiulcer activity. ${ }^{16}$

Before Treatment, A.T. After treatment. \#: Recovering gradually from white diarrhea, depression, freshness of feathers, healthy eyes, slowly reduced loud chirping, vent pasting, gasping and lameness.

Further, this plant was reported by several researchers for its antihelminitic, ${ }^{17}$ antihyperglycaemic, ${ }^{18}$ antioxidant, hepatoprotective and wound healing activity, ${ }^{15}$ anti diabetic ${ }^{18}$, antipyretic and cholesterol-lowering activity ${ }^{19,20}$. Similar kind of study was performed and documented by Ahmad Ziarlarimi et al. ${ }^{10}$ has reported that the medicinal plants such as Allium cepa, Mentha spp and Allium sativum instead of using antibiotics to control the infection of Escherichia coli (Colibacillosis) in broiler chickens. ${ }^{10}$ But there was no research report available 
among the research community about medicinal use of $T$. chickens caused by S. pullorum. dioica against bacillary white diarrhea disease on broiler

Table I The mean weight of chicks at before and after treatment and mean feed intake during treatment (4 days treatment)

\begin{tabular}{|c|c|c|c|c|c|c|c|c|c|}
\hline \multirow{2}{*}{ S.No. } & \multirow{2}{*}{ Treatment } & \multirow{2}{*}{$\begin{array}{l}\text { Mean weight of } \\
\text { chickens (B.T.) } \\
\text { in gram }\end{array}$} & \multirow{2}{*}{$\begin{array}{l}\text { Chickens } \\
\text { lived after } \\
\text { treatment } \\
\text { (out of } 3 \text { No.) }\end{array}$} & \multicolumn{4}{|c|}{$\begin{array}{l}\text { Disease recovery percentage (\%) } \\
\text { on day basis ( } 4 \text { days). based on\# }\end{array}$} & \multirow{2}{*}{$\begin{array}{l}\text { Mean chickens } \\
\text { weight (A.T.) in } \\
\text { gram }\end{array}$} & \multirow{2}{*}{$\begin{array}{l}\text { Mean feed } \\
\text { intake (gm) }\end{array}$} \\
\hline & & & & I & 2 & 3 & 4 & & \\
\hline I & T0 & 359.8 & 3 & 15 & 35 & 80 & 100 & 365.2 & 144.7 \\
\hline 2 & TI & 353.6 & 0 & 0 & 0 & 0 & 0 & 0 & 0 \\
\hline 3 & $\mathrm{~T} 2$ & 355.3 & I & 05 & 20 & 45 & 65 & 320.2 & $53.4^{* *}$ \\
\hline 4 & $\mathrm{~T} 3$ & 357.9 & 2 & 10 & 25 & 60 & 80 & 358.4 & 7I. 3* \\
\hline 5 & $\mathrm{~T} 4$ & 354.5 & 3 & 14 & 30 & 75 & 100 & 370.4 & 129.9 \\
\hline 6 & T5 & 353.3 & 3 & 17 & 35 & 80 & 100 & 378.6 & 152.6 \\
\hline 7 & T6 & 355.9 & 3 & 17 & 35 & 80 & 100 & 382.6 & 153.3 \\
\hline
\end{tabular}

**: 2 chickens were died during $2^{\text {nd }}$ day of treatment. $*$ : I chicken was died during $3^{\text {rd }}$ day of treatment.

\section{Conclusion}

Based on this case study, the efficiency of fresh leaves paste of $T$. dioica on bacillary white diarrhea of broiler chickens caused by S. pullorum, are concluded that the fresh leaf paste of $T$. dioica at $2 \mathrm{gm}$ dose with sterile water may effectively cure the disease with four days of continuous medication. Further this study conclude that this plant simultaneously may induce the feed digestibility, feed intake and helpful to increase the weight of chicken gradually. This preliminary data may useful to carry out further research on it against $S$. pullorum infections on broiler chickens.

\section{Acknowledgements}

The authors are would like to thank the PG and Research Centre in Biotechnology, M.G.R. College, Hosur for providing sophisticated laboratory support and thanks to the department of Biotechnology, Periyar University, Salem for their assistance to successfully complete this study.

\section{Conflict of interest}

The author declares that there is no conflict of interest.

\section{References}

1. Gang Zhou, Jungang Wang, Xiaoqi Zhu, et al. Induction of maggot antimicrobial peptides and treatment effect in Salmonella pulloruminfected chickens. JAPR: Research Report. 2014;23(3):376-383.

2. Crhanova $\mathbf{M}$, Hradecka $\mathrm{H}$, Faldynova $\mathbf{M}$, et al. Immune response of chicken gut to natural colonization by gut microflora and to Salmonella enteric serovar Enteritidis infection. Infect Immun. 2011;79(7):27552763.

3. Fratamico PM. Comparision of culture, polymerase chain reaction (PCR), Taq Man Salmonella, and Transia Card Salmonella assays for detection of Salmonella spp. in naturally contaminated ground chicken, ground turkey, and ground beef. Mol Cell Probes. 2003;17(5):215-221.

4. Karaman L, Sahin F, Gulluce M, et al. Antimicrobial activity of aqueous and methanol extracts of Juniperus oxycedrus L. J Ethnopharm. 2003;85:231-235.

5. Bharathi LK, Vishalnath. Phenotypic diversity analysis in pointed gourd (Trichosanthes dioica Roxb.). Cucurbit Genetics Cooperative Report. 2011;33(34):62-64.
6. Sharma G, Pant MC. Effects of feeding Trichosanthes dioica (parval) on blood glucose, serum triglyceride, phospholipid, cholesterol, and high density lipoprotein-cholesterol levels in the normal albino rabbit. Curr Sci. 1988;57:1085-1087.

7. Mukharjee SK. Indian scenario (Abstract-11). India.

8. Prashant Kumar Rai, Dolly Jaiswal, Rakesh Kumar Singh, et al. Glycemic properties of Trichosanthes dioica leaves. Pharma Bio. 2008;46(12):894 899.

9. Rai DK, Rai PK, Jaiswal D, et al. Effect of water extract of Trichosanthes dioica fruits in streptozotocin induced diabetic rats. Ind J Clin Biochem. 2008;23(4):387-390.

10. Ahmad Ziarlarimi, Mehrdad Irani, Shahabodin Gharahveysi. An investigation on the replacement of antibiotics by medicinal plants to control the infection of Escherichia coli (E. coli) in broiler chickens. Afri J Biotech. 2011;10(56):12094-12097.

11. Salaheen S, Nguyen C, Mui C, et al. Bioactive berry juice byproducts as alternative and natural inhibitors for Salmonella gallinarum and Salmonella pullorum. J Appl Poult Res. 2015;24(2):186-197.

12. Hamdulay N, Attaurrahaman Z, Shende V, et al. Evaluation of gastric antiulcer activity of Trichosanthes dioica Roxb. leaves. Int J Pharm Sci Res. 2012;3(11):4332-4337.

13. Sharmila BG, Kumar G, Rajasekara PM. Cholesterol-lowering activity of the aqueous fruit xxtract of Trichosanthes dioica Roxb (L.) in normal and Streptozotocin diabetic rats. J Clinical Diagno Res. 2007;1(6):561-569.

14. Ghaisas MM, Tanwar MB, Ninave PB, et al. Hepatoprotective activity of aqueous and ethanolic extract of Trichosanthes dioica Roxb. in ferrous sulphate-induced liver injury. Pharmacolo. 2008;3:127-135.

15. Shivhare Y, Singh P, Patil UK. Healing Potential of Trichosanthes dioica Roxb on Burn Wounds. Res J Pharm Pharmaco. 2010;2(2):168-171.

16. Yesilada E, Takaishi Y. A saponin with antiulcerogenic effect from the flowers of Spartium junceum. Phytochemistry. 1999;51(7):903-908.

17. Bhattacharya S, Haldar PK, Ghosh AK. An in vitro effect of Trichosanthes dioica leaves on annelids and nematodes. Pharmacolo. 2009;2:242-248.

18. Prashant Kumar Rai A, Dolly Jaiswal A, Sandhya Diwakar B, et al. Antihyperglycemic Profile of Trichosanthes dioica seeds in experimental models. Pharma Bio. 2008;46(5):360-365.

19. Bhargava S, Bhargava P, Saraf S, et al. Evaluation of antipyretic activity of sudarshan churna: an Ayurvedic formulation. J Res Educ Indian Med. 2008;3:11-14.

20. Singh K. Pointed gourd (Trichosanthes dioica Roxb.). Indian Hort 1989;33:35-38 